\title{
Opettaja kiusaamisen kohteena
}

\author{
Teemu Kauppi \\ yliopistonlehtori, FT \\ Lapin yliopisto
}

teemu.kauppi@ulapland.fi

Lectio praecursoria puheviestinnän väitöskirjaksi tarkoitetun tutkimuksen Opettaja kiusattuna. Peruskoulun opettajien kokemuksia vertaisrajat ylittävästä kiusaamisesta tarkastustilaisuudessa Jyväskylän yliopistossa 23.5.2015. Vastaväittäjänä toimi dosentti Anne Konu (Tampereen yliopisto) ja kustoksena dosentti Maili Pörhölä.

Vuorovaikutussuhteemme ovat pääosin sävyltään positiivisia ja meille antoisia. Valitettavasti näin ei ole aina ja kaikkialla. Joskus vuorovaikutussuhteemme sisältävät myös negatiivisia sävyjä ja ne saattavat joskus saada jopa meitä vahingoittavia muotoja. Julkisuudessa on viime vuosina keskusteltu kiivaaseenkin sävyyn työyhteisöissä esiintyvästä työpaikkakiusaamisesta. Esimerkiksi joihinkin kiusaamistapauksiin liittyvät oikeudenkäynnit ovat olleet varsin laajan uutisoinnin kohteena. Mediassa keskustellaan säännöllisesti myös kouluissa oppilaiden välillä ilmenevästä koulukiusaamisesta. Koulukiusaamista ja työpaikkakiusaamista on myös tutkittu kohtalaisen paljon useissa eri maissa. Julkisessa keskustelussa on viime vuosina myös nostettu säännöllisesti keskustelun aiheeksi opetustyössä koettu kiusaaminen oppilaiden ja heidän vanhempiensa taholta. Silloin tällöin mediassa keskustellaan myös opettajien harjoittamasta kiusaamisesta oppilaitaan kohtaan. Opetustyössä koettua kiusaamista on kuitenkin tarkasteltu tieteellisissä tutkimuksissa huomattavan vähän sekä kansainvälisesti että Suomessa. Aiheeseen liittyvää vähäistä tutkimustietoa voidaan pitää monin tavoin yllättävänä. Tällä hetkellä suomalaiset opettajat ovat vastuussa yli puolen miljoonan peruskoulun oppilaan koulutyöstä ja hyvinvoinnista. Voidaan olettaa, että jos opettajat voivat huonosti, he eivät myöskään pysty tukemaan oppilaidensa koulutyötä tai kodin ja koulun yhteistyötä 
parhaalla mahdollisella tavalla. Opettajien työssään kohtaamat ongelmat koskettavatkin huomattavan monia kouluyhteisön jäseniä.

Tutkimuksissa on todettu, että opettajat, jotka pystyvät muodostamaan oppilaidensa kanssa positiivisia vuorovaikutussuhteita, ovat muita tyytyväisempiä työpaikkaansa ja pysyvät kollegoitaan useammin motivoituneina työtään kohtaan. Toisaalta esimerkiksi oppilaiden ongelmakäyttäytymisen on todettu olevan merkittävä stressitekijä opettajan työssä. Erityisen kuormittavaksi työ muodostuu, jos työntekijä kokee vuorovaikutuksen ongelmat kiusaamisena. Useissa tutkimuksissa on todettu, että työssä koettu kiusaaminen vaikuttaa monin tavoin negatiivisesti työntekijöiden hyvinvointiin, sosiaaliseen elämään ja terveyteen.

Kiusaaminen on pohjimmiltaan viestinnällinen ilmiö. Ollessaan keskenään vuorovaikutuksessa viestinnän osapuolet luovat jatkuvasti uusia merkityksiä toistensa viestinnälle. Viestinnän avulla siis luodaan ja muokataan sosiaalista todellisuutta. Vuorovaikutuksen voidaan kuvata olevan kuin tennisottelu, jossa pallo lähetetään verkon toiselle puolelle, minkä jälkeen toinen pelaaja mukauttaa toimintansa sen mukaisesti, mihin hän olettaa tai näkee pallon laskeutuvan. Hän palauttaa pallon takaisin verkon toiselle puolelle, jossa toinen pelaaja jo suunnittelee, ennakoi ja säätelee omaa reaktiotaan sen mukaisesti, mihin pallo on matkalla. Jossain vaiheessa pallottelu pysähtyy hetkeksi, kun toinen ei enää ylety palloon. Ottelun jatkuessa pallottelu kuitenkin alkaa aina uudestaan ja uudestaan. Jokaisen pallottelun kulku muovautuu pelaajien liikkeen myötä aina uuden näköiseksi. Yksikään pallottelu ei ole keskenään täysin identtinen.

Tennisottelun tavoin viestintätilanteet muovaavat jatkuvasti itseään tilanteille annettujen merkitysten ja osapuolten reagoinnin myötä. Ei ole olemassa kahta täysin samanlaista vuorovaikutustilannetta. Ei ole myöskään olemassa kahta keskenään täysin identtistä kiusaamistilannetta. Kiusaamistilanteissa on kyse vuorovaikutusprosessista, joka perustuu aina viestinnän osapuolen subjektiiviseen kokemukseen siitä, että toinen osapuoli toimii tilanteessa loukkaavasti. Viesti ei ole loukkaava, jos viestin vastaanottaja ei sitä sellaiseksi tulkitse. Toisaalta viesti saattaa olla vastaanottajan mielestä loukkaava, vaikka viestin lähettäjä ei sitä sellaiseksi tarkoittaisi. Puhutun ja kirjoitetun kielen lisäksi sanaton viestintämme on sosiaalisissa tilanteissa jatkuvasti muiden ihmisten potentiaalisen tulkinnan kohteena. Saatamme sanojemme ja eleidemme myötä tulla viestineeksi muille asioita, joille toinen osapuoli antaa aivan eri merkityksen kuin oli tarkoituksemme. Valitettavasti saatamme joskus loukata muita ihmisiä myös aivan tieten tahtoen. Loukatessamme muita sorrumme epäeettiseen viestintään. Kiusaamisen on kuvattu olevan epäeettistä 
viestintää, joka vahingoittaa toista osapuolta.

OAJ:n viime vuonna julkaisema laaja työolobarometri osoitti, että noin joka neljäs suomalaisista peruskoulun opettajista koki joutuneensa epäasiallisen kohtelun tai kiusaamisen kohteeksi oppilaidensa taholta edeltäneen lukuvuoden aikana. Opettajista noin joka kuudes oli kokenut epäasiallista kohtelua oppilaiden huoltajien taholta. Monet vastaajista ilmoittivat jopa sairastuneensa kokemansa epäasiallisen kohtelun vuoksi. Oikeuspoliittisen tutkimuslaitoksen selvitys muutamaa vuotta aiemmin nosti esiin samansuuntaisia havaintoja suomalaisten opettajien kokemuksista. Tietämys peruskoulun opettajien kokemuksista rajoittuu kuitenkin yksittäisten selvitysten tarjoamaan kuvaan siitä, että huolestuttavan monet opettajat kohtaavat työssään henkistä tai fyysistä väkivaltaa.

\section{Tutkimuksen tavoitteet ja toteutus}

Väitöskirjatyötä aloittaessani ei ollut juuri selvitetty sitä, millaista on suomalaisiin peruskoulun opettajiin kohdistuva toistuva kiusaaminen. Myöskään kiusaamisen viestinnällisiin piirteisiin ei ollut kiinnitetty huomiota kovinkaan laajasti. Lähdinkin tutkimuksessani selvittämään sitä, millaisia ovat opettajiin kohdistuvan kiusaamisen ilmenemismuodot, millaiset oppilaat kiusaavat opettajiaan sekä sitä, miten opettajat selittävät kokemuksiaan ja kenelle he kertovat kiusaamisesta. Pääpaino tutkimuksessani suuntautui oppilaiden opettajiin kohdistamaan kiusaamiseen. Tutkimukseni pienemmissä osakokonaisuuksissa tarkastelin myös opettajien kokemaa kiusaamista oppilaiden vanhempien taholta sekä oppilaiden kokemaa kiusaamista opettajiensa taholta. Kaikille näille kiusaamisasetelmille tunnusomaista on se, että kiusaamisen osapuolet eivät ole koulussa samantasoisessa asemassa. Opettajalla on koulussa ammattiasemaansa perustuvaa valtaa, jota oppilailla ja heidän vanhemmillaan ei ole. Oppilaiden ja opettajien sekä oppilaiden vanhempien ja opettajien välisiä kiusaamissuhteita voidaankin kuvata käsitteellä vertaisrajat ylittävä kiusaaminen.

Väitöskirjatutkimukseeni sisältyy neljä julkaistua tieteellistä artikkelia, joissa koulun vertaisrajat ylittäviä kiusaamissuhteita tarkastellaan eri näkökulmista. Käytin tutkimusmenetelminä sekä metasynteesiä toteuttamissani kirjallisuuskatsausartikkeleissa että empiiristä tutkimusaineistoa. Empiirisen tutkimusaineistoni avulla tavoitteeni oli selvittää kiusatuksi joutuneiden opettajien omakohtaisia kokemuksia kiusaamisesta. Keräsin empiirisen tutkimusaineistoni kyselylomakemenetelmällä internetkyselynä lukuvuoden 2008-2009 aikana. Kysely lähetettiin satunnaisesti valituille kouluille eri puolelle Suomea. Kyselyn vastaanottaneet koulut olivat 
etukäteen ilmaisseet halunsa osallistua tutkimukseen. Yhteensä 215 peruskoulun opettajaa vastasi kyselyyn.

Oppilaiden opettajiin kohdistaman kiusaamisen kuvattiin tutkimuksessani tarkoittavan sitä, että "Opettaja joutuu toistuvasti yhden tai useamman oppilaan taholta sellaisen viestinnän kohteeksi, jonka opettaja kokee loukkaavaksi, kiusalliseksi tai uhkaavaksi. Kiusaaminen voi olla sanallista, sanatonta tai fyysistä." Vastaajista 70 oli kokenut kiusaamista oppilaiden taholta ja 78 oppilaiden vanhempien taholta. Lukumäärien perustella ei kuitenkaan ole mahdollista arvioida kiusaamisen yleisyyttä, eikä se myöskään ollut tutkimuksen tavoitteena.

\section{Tulokset ja johtopäätökset}

Empiiriseen aineistooni perustuneet tulokset osoittivat, että opettajat joutuivat oppilaidensa taholta hyvin monimuotoisen kiusaamisen kohteiksi. Kiusaaminen ilmeni tyypillisesti sekä suorana että epäsuorana kiusaamisena. Tyypillisimpiä kiusaamisen muotoja olivat hävyttömät ja asiattomat oppilaiden kommentit, yhteistyöstä kieltäytyminen, toistuva valehtelu opettajalle sekä opettajan pilkkaaminen ja hänelle naureskelu. Opettajiin myös kohdistettiin loukkaavaa elehdintää ja oppilaat saattoivat piiloutua tai myöhästellä toistuvasti. Monet opettajat kokivat kiusaamisena myös heidän viestintänsä matkimisen sekä toistuvan opettajan huomiotta jättämisen.

Opettajat arvioivat joutuneensa useimmin poikaoppilaiden kiusaamiksi. Koulukiusaamista käsitelleet aiemmat tutkimukset ovat osoittaneet, että muita oppilaita kiusaava oppilas on hieman useammin poika kuin tyttö. Poikien rooli kiusaajana näyttäisi kuitenkin erityisesti korostuvan kun kiusaamisen kohteena on opettaja. Opettajat arvioivat, että tyypillisesti heihin kohdistuneeseen kiusaamiseen osallistui yksittäinen oppilas tai pieni oppilasjoukko. Huomattava vähemmistö vastaajista koki joutuneensa suuren oppilasjoukon kiusaamaksi. Tyypillisesti opettajia kiusasivat oppilaat, joita he opettivat tutkimuksen ajankohtana. Huomattavaa kuitenkin oli, että monet vastaajista olivat kokeneet kiusaamista myös sellaisten oppilaiden taholta, joita he eivät olleet koskaan opettaneet. On mahdollista, että tällöin oppilaat esimerkiksi tavoittelivat oman statusasemansa nostamista muiden oppilaiden silmissä. Opettajat myös arvioivat, että usein heitä kiusanneet oppilaat kiusasivat koulussa myös oppilastovereitaan.

Selvitin myös sitä, miten opettajat selittivät joutumistaan oppilaiden kiusaamiksi. Useimmin opettajat selittivät kiusaamista oppilaslähtöisillä 
tekijöillä, joita olivat esimerkiksi oppilaan terveyteen tai henkiseen tilaan liittyvät tekijät, tarve erityisopetukselle tai erityishuomiolle sekä ongelmat kotikasvatuksessa. Toiseksi useimmin kiusaamista selitettiin kouluinstituutioon liittyneillä tekijöillä. Tyypillisesti vastaajat kuvasivat tällöin sitä, että he edustavat asemansa puolesta auktoriteettia koulussa ja kiusaaminen oli suunnattu opettajien tulkinnan mukaan tätä auktoriteettia vastaan. Huomattava vähemmistö opettajista piti kiusaamisen syynä omia piirteitään tai omaa viestintäänsä.

Huomioitavaa tuloksissa oli, että kiusaamisen nähtiin useimmiten johtuvan tekijöistä, joihin opettajat eivät juuri itse pysty vaikuttamaan. Oppilaiden piirteet ja opettajan ammattiasema ovat tällaisia tekijöitä. On todennäköistä, että oppilaiden piirteet tai heidän halunsa kapinoida opettajan edustamaa auktoriteettia vastaan ovatkin usein syitä opettajiin kohdistuvaan kiusaamiseen. Kuitenkin jos kiusaaminen johtuisi ainoastaan näistä tekijöistä, voitaisiin olettaa, että kaikki samankaltaisissa työtehtävissä ja samojen oppilaiden kanssa työskentelevät opettajat joutuisivat yhtälailla kiusatuiksi. Todennäköisesti näin ei kuitenkaan ole. Tulevaisuudessa voitaisiinkin selvittää esimerkiksi opettajien viestintätaitojen ja viestintätyylin sekä pedagogisten käytänteiden yhteyttä heidän kiusaamiskokemuksiinsa. Tämänkaltainen ymmärrys olisi hyödyksi esimerkiksi opettajankoulutuksessa.

Opettajat olivat kertoneet kokemastaan kiusaamisesta useimmin työtovereilleen tai esimiehelleen. Tulokset osoittivat myös selkeän yhteyden kiusaamiselle annettujen selitysten ja kiusaamisesta kertomisen välillä. Lähes kaikki vastaajat, jotka selittivät kokemaansa kiusaamista ainoastaan oppilaiden piirteillä tai opettajan ammattiasemalla olivat keskustelleet kokemuksistaan useimmin työyhteisönsä sisällä. Sen sijaan kaikki opettajat, jotka näkivät kiusaamisen johtuvan vain omista piirteistään tai toiminnastaan, olivat kertoneet kiusaamisesta useimmin työyhteisönsä ulkopuoliselle henkilölle tai eivät olleet kertoneet kokemuksistaan kenellekään. Tulevaisuudessa olisikin tarpeellista rohkaista ja auttaa kouluja entistä paremmin luomaan työyhteisöihin sellainen ilmapiiri, jossa kaikki kiusaamista kokeneet opettajat uskaltaisivat kertoa kiusaamiskokemuksistaan avoimesti myös työyhteisön sisällä. Todennäköisesti tämä auttaisi työyhteisön jäseniä löytämään käytännön ratkaisuja kiusaamisongelmiin puuttumisessa.

Pienempi osa empiirisestä aineistostani käsitteli opettajien kokemaa kiusaamista oppilaiden vanhempien taholta. Tulokset osoittivat, että tyypillisiä kiusaamisen muotoja vanhempien taholta olivat epäoikeudenmukaiseksi koettu ammattitaidon tai opettajan persoonan arvostelu, 
epäasiallinen kielenkäyttö tai opettajan maineen mustaaminen. Useat opettajat kokivat kiusaamisena myös toistuvat tilanteet, joissa opettaja ilmoitti oppilaan kotiin koulupäivän tapahtumista ja oppilaan vanhemmat eivät uskoneet opettajan kertomusta, joka saattoi olla ristiriidassa oppilaan version kanssa. Erityislaatuiseksi opettajien ja oppilaiden vanhempien välisen kiusaamisasetelman tekee se, että vaikka kiusaaminen ilmenee kahden aikuisen välisessä vuorovaikutuksessa, mukana on tavallaan myös kolmas osapuoli, oppilas. Vaikka oppilas ei olisi fyysisesti paikalla näissä kiusaamistilanteissa, aikuisten välillä ilmenevä kiusaaminen kuitenkin usein kumpuaa oppilasta koskevista asioista. Huomattavaa oppilaiden vanhempien ja opettajien välisissä kiusaamissuhteissa on myös se, että kiusaaminen ilmenee usein teknologiavälitteisesti, koska opettajien ja vanhempien yhteydenpito on usein muutoinkin teknologiavälitteistä.

Selvitin tutkimuksessani myös, mitä aiempien tutkimuksien perusteella tiedetään kiusaamisesta, jota oppilaat kokevat opettajiensa taholta. Tätä kiusaamisasetelmaa selvitin ainoastaan tarkastelemalla aiempia tutkimuksia aiheesta, en oman empiirisen aineistoni avulla. Analyysini osoitti, että oppilaiden kokemasta kiusaamisesta opettajiensa taholta tiedetään toistaiseksi vain vähän. Eri maissa tehtyjen tutkimusten ja selvitysten perusteella vaikuttaisi kuitenkin siltä, että oppilaat saattavat kokea myös opettajiensa viestinnän kiusaamisena. Yksittäisten selvitysten perusteella vaikuttaisi siltä, että näin on myös suomalaisissa kouluissa. Tulevissa tutkimuksissa näitä koulun kiusaamissuhteita olisi tarpeellista tarkastella tarkemmin. Nykytilanteessa on mahdollista, että opettajiensa kiusaamiksi joutuneiden oppilaiden kokemukset eivät saa ansaitsemaansa huomiota kouluissa tai opettajankoulutuksessa, koska ilmiötä ei toistaiseksi tunneta kovin syvällisesti.

Kaiken kaikkiaan tulevissa vertaisrajat ylittävää kiusaamista kartoittavissa tutkimuksissa olisi hedelmällistä kiinnittää aiempaa enemmän huomiota oppilaiden ja opettajien välisten kiusaamissuhteiden kehittymiseen. Voidaan olettaa, että usein kiusaamista ei ala esiintyä heti oppilaan ja opettajan ensitapaamisella. Tulevissa tutkimuksissa voitaisiin myös kiinnittää huomiota siihen, miten opettajat toimivat tilanteissa, joissa he kokevat joutuvansa oppilaidensa kiusaamiksi. Opettajien toimintastrategioiden tuntemus olisi tärkeää, jotta esimerkiksi opettajankoulutuksessa voitaisiin kiinnittää aiempaa enemmän huomiota siihen, millaiset toimintamallit auttavat opettajia selviämään kiusaamisprosesseissa.

Väitöskirjatutkimukseni tuloksia voitaisiin tulevaisuudessa hyödyntää myös koulukiusaamisen vähentämiseen tähtäävien interventio-ohjelmien kehittämisessä. Interventio-ohjelmat todennäköisesti hyötyisivät 
siitä, että niissä otettaisiin aiempaa laajemmin huomioon myös koulussa ilmenevät vertaisrajat ylittävät kiusaamissuhteet. Tutkimukseni tuloksia voidaan hyödyntää myös esimerkiksi kiusaamista kokeneiden opettajien työnohjauksessa.

Tutkimukseni tuloksia ja sen esiin nostamia kysymyksiä olisi tarpeellista käsitellä myös koulujen rehtoreiden koulutuksessa työsuojelun näkökulmasta. Kouluissa rehtorit toimivat opettajien esimiehinä ja heidän velvollisuuksiinsa kuuluu ryhtyä toimenpiteisiin, jos he saavat tiedon koulunsa työntekijään kohdistuvasta vahingoittavasta käyttäytymisestä. On tärkeää, että heillä on tukenaan tutkimustietoa, kun he yrittävät löytää tehokkaita toimintamalleja kiusaamisongelmien selvittämiseksi.

Tutkimukseni tuloksia voitaisiin hyödyntää myös koulujen arjessa. Opettajat voisivat keskustella oppilaidensa kanssa siitä, että samoin kuin oppilastoverit, opettajakin saattaa kokea oppilaiden viestinnän kiusaamisena. On myös mahdollista, että oppilas kokee opettajan kiusaavan häntä. Mahdollisesti tämänkaltaiset keskustelut auttaisivat oppilaita tunnistamaan heidän oman viestintänsä eettisiä ulottuvuuksia, mikä saattaisi vaikuttaa myönteisesti heidän vuorovaikutustaitojensa kehittymiseen. Koulun vertaisrajat ylittävistä kiusaamissuhteista olisi tarpeellista keskustella myös oppilaiden vanhempien kanssa. Mahdollisesti oppilaiden vanhemmat tulisivat avoimen keskustelun myötä myös tietoisemmiksi siitä, että opettajat saattavat kokea myös heidän viestintänsä kiusaamisena.

Voidaan kaikkinensa olettaa, että tutkimustieto ja sen ruokkima avoin keskustelu vertaisrajat ylittävästä kiusaamisesta on monin tavoin tarpeellista, jotta opettajat, oppilaat ja heidän vanhempansa voisivat aiempaa paremmin muodostaa toistensa kanssa sellaisia vuorovaikutussuhteita, jotka olisivat kaikille osapuolille hedelmällisiä ja tukisivat mahdollisimman hyvin heidän hyvinvointiaan. Toivonkin, että tutkimukseni toimii keskustelunavauksena, jonka myötä koulun vertaisrajat ylittäviin kiusaamissuhteisiin kiinnitetään tulevaisuudessa aiempaa enemmän huomiota. 